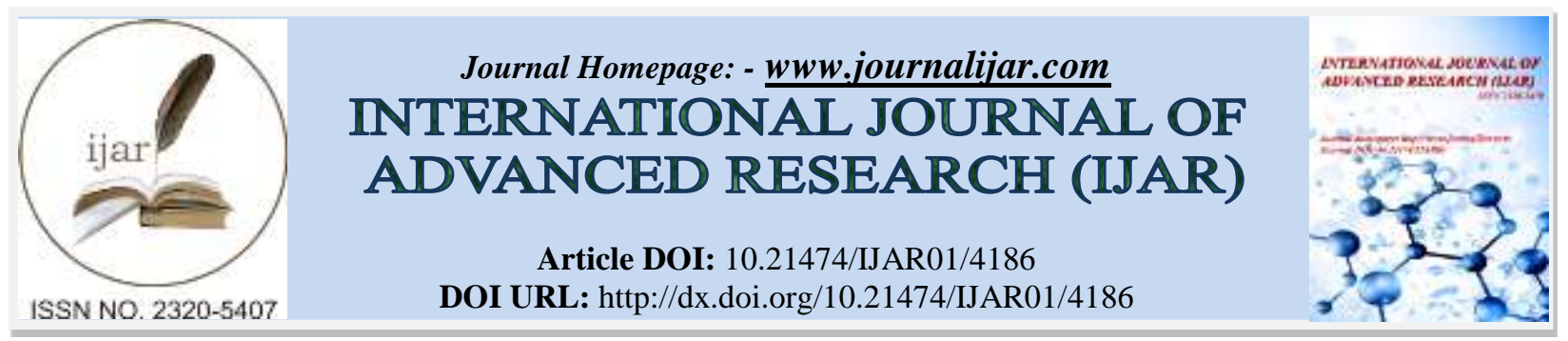

RESEARCH ARTICLE

\title{
A REFLECTION ON LEGAL LIABILITIES OF PUBLIC ACCOUNTANT: PHENOMENOLOGICAL STUDY IN THE FRAMEWORK OF MASCULINE AND FEMININE VALUES.
}

\author{
Luky Patricia Widianingsih.
}

Accounting Study Program, Universitas Pelita Harapan Surabaya, Jl. Jend. A. Yani 288 Surabaya, Indonesia 60234.

\section{Manuscript Info}

Manuscript History

Received: March 2017

Final Accepted: 01 April 2017

Published: May 2017

Key words:-

Legal liability, public accountant, masculine value, feminine value.

\section{Abstract}

Legal liability may arise as public accountant gives professional services. The objective of this research is to gain insight into awareness of legal liability on the part of public accountant in gender perspective. This research is qualitative in interpretive paradigm that seeks to understand awareness of legal liability of public accountant. Phenomenology is used as approach to seek meaning in the research site. Gender in dual ideologies, masculine and feminine are used to frame derived insights. Explorations in the realm of practices produce synthesized insight into legal liability such as: firstly, legal liability as evidence of professionalism; secondly, legal liability as a form of selfprotection; thirdly, legal liability as manifestation of compliance and finally fourthly, legal liability as part of moral responsibility. Therefore a conclusion can be drawn that the meaning of professionalism as masculine values, whereas the meaning of selfprotection, compliance and morality as feminine values.

Copy Right, IJAR, 2016,. All rights reserved.

\section{Introduction:-}

Legal liability may arise when auditors provide professional services. So many violations of professional practice conducted by public accountants and public accounting firm, imply a big question on how exactly their awareness of legal aspects that are also inherent in the profession. Noble values that form the accountants are personally sacred duty to uphold the profession seems to have been marginalized by the whims of mere mortals. Plus expectation gap between auditors and clients (the public) about the responsibilities of an auditor of the audited financial statements. Differences in expectations (expectation gaps) between the auditor with the public and/or users of financial statements in view of auditors' responsibilities in detecting and reporting fraud by the management is causing the threat of litigation for auditors (Irianto, 2003). Because of that the auditors have to be careful in performing their duties for the parties who use the services of these professions (Kholis, 2001).

Awareness of legal liabilities of a public accountant can be influenced by internal factors or external factors. Susanto (2003) in his research found that the internal variables such as motivation, learning and moral development have simultaneous influence on the independent auditors' perceptions regarding the implementation of legal obligations, but partially only motivation and moral development variables that significantly influence the perception of the independent auditors regarding the implementation of legal obligations. In addition to these internal factors, awareness of legal liabilities can also be affected by external factors such as the existence of sanctions for violations committed by public accountants. In a study of perceptions of public accountants regarding the application of private litigation as a sanction violation of professional code of ethics, Yunitasari (2002) found that the public accounting 
profession cannot be exempted from legal sanctions or regulations that apply. Sanctions are deemed to be necessary in order to establish control over the public accounting profession. Although there are still doubts that certain clauses in the legislation can now be used to capture perpetrators of professional code of ethics, but basically a public accountant supports the implementation of the Private Litigation as a sanction to violations of professional code of ethics.

On the one hand the legal liabilities of an accountant as demanded by profession service users increase, but on the other hand we are faced with the fact that there are many legal violations in the professional practices involving accountants. Gender analysis is an analytical tool for understanding social reality. It does not only see the accountants (auditor) as a biological body, but also as a male or female; and this course has been studied before, but more than that, how the ideology of masculinity versus femininity may exist outside "their body". This research was conducted in a natural setting on the reality of life in the public accounting firm. The research in the natural setting was done on the basis of the fact that the accounting profession is currently experiencing pressure due to the moral crisis that engulfed (Ludigdo, 2005). This study uses an interpretive paradigm to analyze the issue in question. Gender analysis as such like any other social theory is an analytical tool for understanding social reality. As stated by Kholis et al (2001), in order to gain an understanding of consciousness is a legal liability in accounting profession, an in-depth study needs to be done either scientifically (on the theoretical level) or empirically in its implementation in the field aiming at obtaining a comprehensive picture of this proposal. Starting from what has been disclosed above; the focus of this research is attempts to gain an understanding of awareness of public accountants' legal liabilities in the framework of masculine and feminine.

Basis For Understanding The Legal Liabilities Of Accountants:-

Ganado (2007) reveals that responsibilities arise because a person suffers a loss as a result of any act or omission of an accountant or auditor. And a person liable for damages only if it can be connected to his actions - the principles of cause and effect (Ganado, 2007). Ganado's meaning is used to state that someone is blamed for an action. Legal liabilities as well understood in this study involving equivalent to a legal duty or legal obligation. The idea of "duty" arises because the characteristics of the legal norms contain the meaning of "binding" or "emphasizing obedience" (Sumaryono, 2002). The responsibility comes not only because there are simply those who suffer, but far from it due to the existence of binding social contract between individual human beings causes human beings to have the responsibility.

Responsibility of auditors (including legal liability) in order to assess the fairness of the financial statements of a material misstatement is a reflection of behavior enacted by the auditor related to their professional ethics (Saleh, 2005). This constitutes is the responsibility toward. Two standards that need to be considered by an accountant to audit the financial statements of companies are: Standards Audit (SA) Section 316 - PSA No. 70 regarding the consideration of fraud in financial statement audit and the Standards Audit (SA) Section 317 - PSA No. 31 of the element of unlawful actions by the client. Both PSA is specifically about the steps that need to be taken by the auditors if they find an indication of the violation of law, or fraud made by the management company (IAI-KAP, 2001).

By agreeing to perform services for the client, then an auditor or public accountant is in a direct contractual relationship with its clients. The term personal relationships in the contract (privities of contract) here are intended to clarify existing contractual relationship between two or more parties involved in the contract. An accountant will be responsible to the client in accordance with the laws of contract and unlawful act (tort law). In addition to client responsibilities as described above, there are also responsibilities to third parties. Third parties can be interpreted as not knowing about the parties involved in the contract. Auditors are responsible to all third parties for any gross negligence and fraud under the terms of unlawful act (tort law). Meanwhile the responsibility of auditors for ordinary negligence is different between the two groups of such third parties. An example of potential claims in this case is a third party such as a bank that requires the auditor not to find a material misstatement in the financial statements (Arens and Loebbebke, 1997).

\section{Research Method:-}

\section{Qualitative Approaches in Interpretive Paradigm:-}

This study uses a qualitative approach that emphasizes the humanistic approach to the understanding of social reality. This approach sees the world as roundness (holistic) with the assumption that the understanding of human behavior is not enough just with surface behavior but also the perspective within the human actors to obtain a 
complete picture of the man and his world. This approach is suitable in research using gender perspective aiming to create a society that is free from the characteristics of misfortunes in various forms (Handayani and Sugiarti, 2006). Through a qualitative approach within an interpretive paradigm will be the description of the attitudes, views, and the behavior of those being investigated. Interpretive paradigm seeks to recognize the world as it is, with his own subjective experience approach (Burrell and Morgan, 1979). This paradigm is related to understanding the essence of the everyday world. The orientation is aimed to obtain more subjective understanding of creation "as it exists" of a process that takes place (Burrell and Morgan, 1979).

\section{Understanding Behavior of Accountants in Phenomenology:-}

Qualitative approach is based on phenomenological philosophy (Handayani and Sugiarti, 2006; Moleong, 2005, Muhadjir, 2000). Phenomenology is a view of thinking that emphasizes the focus on human subjective experiences and interpretations of the world. As the field of modern philosophy, phenomenology of experience investigates the perpetrators of history of consciousness (or consciousness itself), and this helps a great deal to investigators (Moleong, 2005). The phenomenologist assumes that consciousnesses is not formed by chance and shaped by something other than its own entity. As a community, in a Public Accounting Firm, complex interactions certainly take place; they have the interactions occurring between individuals or institutional interactions. Any individual with a position and a different background would have a different understanding of values, particularly of the meaning of legal responsibility. Researchers try to uncover this phenomenon to get a picture that reflects the circumstances.

\section{Gender Dimensions of Masculinity-Femininity in order to Observe Accountants in Practice:-}

The concept of gender is inherent in the nature of men and women who are shaped by social as well as cultural factors (Handayani and Sugiarti, 2006). Gender labeling is not limited to humans but can also be given to the naming of a term or the other if the characteristic behavior can be represented (Mufidah, 2003). With an interpretive research, the task of theory in this paradigm is to interpret (or to understand). The quality of the theory in this paradigm is measured from its ability to interpret, rather than its ability to explain and predict (Triyuwono, 2006). Therefore the researchers will see the reflection of awareness of the legal liabilities of accountants using a gender lens. Masculinity and femininity are two different and contradictory ideologies. Femininity is characterized by an ideology of peace, safety, love and togetherness. While masculinity has the characteristics: competition, domination, exploitation and oppression (Fakih, 2006). Firestone (in Tong, 2006) reveals that the "masculine response" to reality is a "technological responses"- the "objective, logical, extrovert, realistic, and are associated with consciousness (ego), the rational, mechanical, pragmatic and down to earth". Conversely, "feminine response" to reality is an "aesthetic response" - "subjective, intuitive, introvert, full of hope, full of dreams or fantastic, associated with unconsciousness, emotional, even temperamental." The following is a list of the distinctions between of masculinity and femininity (Handayani and Sugiarti, 2006).

Table.1:- Emotional and Intellectual Differences of Masculine and Feminine Character.

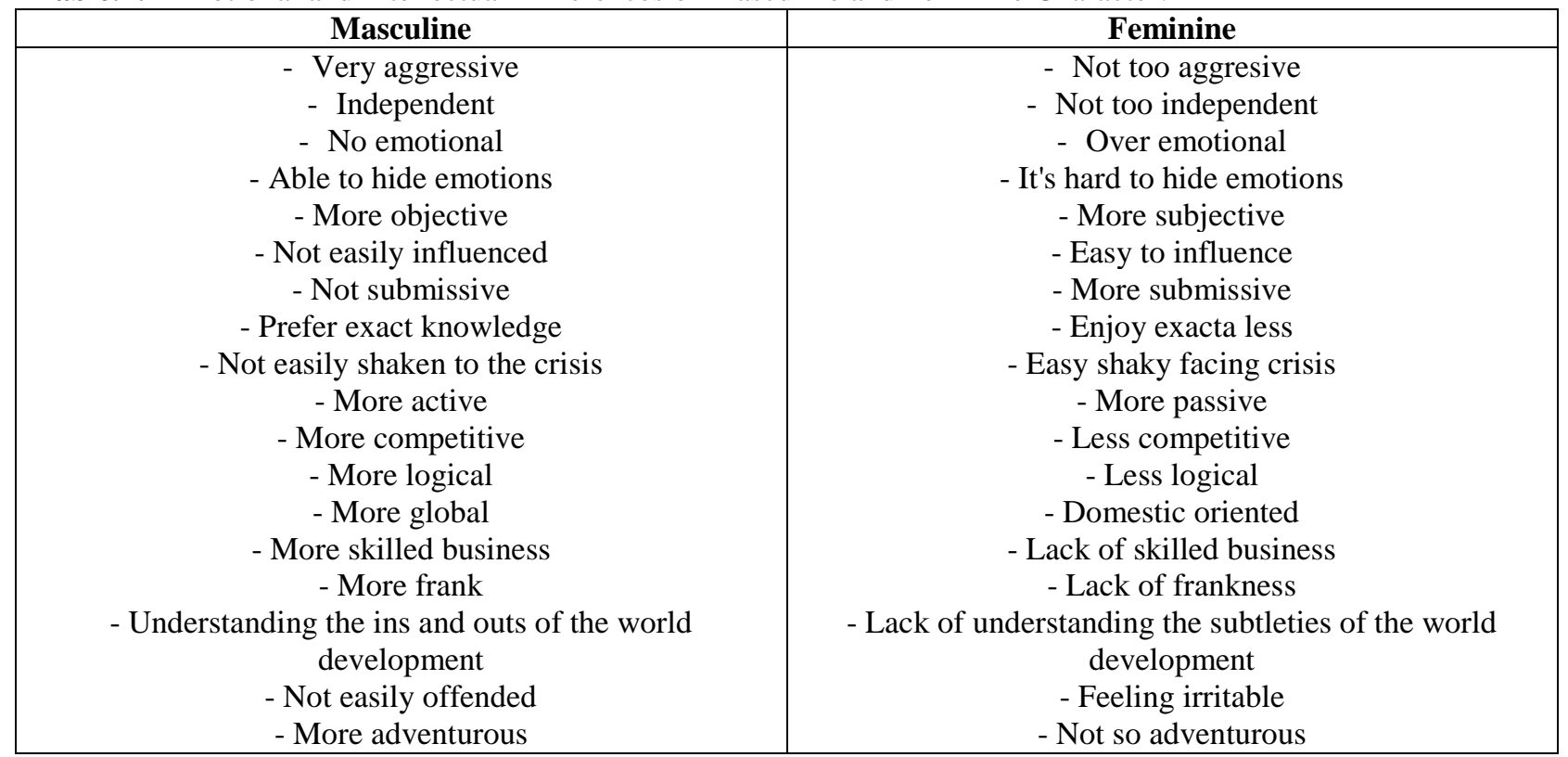




\begin{tabular}{|c|c|}
\hline $\begin{array}{c}\text { - Easy to solve problems } \\
\text { - Rarely crying }\end{array}$ & $\begin{array}{c}\text { - Difficult to overcome problems } \\
\text { - More frequent crying }\end{array}$ \\
- Generally always appear as a leader & $\begin{array}{c}\text { - No publicly featured as a leader } \\
\text { - Fully self-confidence }\end{array}$ \\
- More aggressive attitude & Lack of confidence \\
- Over ambitions & $\begin{array}{c}\text { - Lack of good against an aggressive attitude } \\
\text { - Lack of ambition }\end{array}$ \\
- Easily distinguished by the taste and the ratio & ratio \\
- More independent & - Not easily distinguished by between the taste and the \\
- No awkward in appearance & - Lack of independence \\
- Forward-looking & - More awkward in appearance \\
- More free speech & - Thoughts about winning \\
\end{tabular}

Source. Handayani dan Sugiarti (2006)

\section{Collecting Social Facts and Empirical Data:-}

The process of finding meaning reflected through personality and practical realities in the field is not as easy as to take something that has been "completed". The main source of the data for this research is the words and actions, the rest are the additional data such as documents (Moleong, 2005). Researchers need to have primary data and secondary data an addition (Handayani and Sugiarti, 2006). The main sources of data are recorded through written notes or by recording a video / audiotapes. In depth interviews with the subjects of research are conducted here. Observation is conducted by the researcher; this means staying in the community under study and become part of their lives. In processing empirical material, as has been done by Ludigdo (2005), the researcher conducted a threestep analysis of empirical material as follows. Firstly, researchers conducted data reduction. The process includes simplification, abstraction and transformation of raw data, derived from field observation records. Secondly, by domain analysis and the researcher categorized the various expressions of social realities encountered thematically. Thirdly, make a conclusion, verification and reflection.

\section{A Public Accountant as a Unit Analysis:-}

Researcher conducted in-depth interviews with public accountants to obtain comprehensive information that reflects the awareness of legal liabilities of accountants and their understanding of the issues surrounding the related issues. On the basis of the considerations that the managing partner is the dominant decision maker in Public Accounting Firm, especially in a small-medium enterprises, and simultaneously to ease to get into a natural setting in this organization, the researcher treats the managing partner of the accounting firm referred to as the informant / the main participant. The identity of the Public Accounting Firm and the names of informants are pseudonyms in place of their real name. So there are managing partners and some public accountants involved in this research. The interview process takes place in a variety of situations, both within the public accounting firm in order to observe the work atmosphere, or outside the office.

\section{Result and Discusion:-}

Explorations in the realm of practices produce synthesized insight into legal liability such as: firstly, legal liability as evidence of professionalism; secondly, legal liability as a form of individual protection; thirdly, legal liability as manifestation of compliance or obediance and finally fourthly, legal liability as part of moral responsibility. Therefore a conclusion can be drawn that the meaning of professionalism as masculine values, whereas the meaning of self-protection, compliance and morality as feminine values.

\section{Legal Liabilities as Evidence of Professionalism:-}

Understanding the legal liabilities as a form of professionalism is reflected in the handling of audit procedures. Understanding and being aware of this risk, Indri a supervisor who has been long working in Public Accounting Firm reveals:

"... Must know first what the scope of assignment is? From the scope, we get into the deal. Agreements where we try make agreements which really set out mutual rights and obligations of each party. Everything set from there. So in case there will, say, a problem in the future, their mutual, rights and obligations are already known from the inception. And that we require the client to learn first about legal contract as normally practiced here. " 
In addition to understanding the scope of the assignment and legal contract at the beginning of the audit, other factors that also support the understanding of the consciousness in the legal liability are the auditor's experience and vision. This experience and vision determine the sensitivity of the auditor in dealing with clients. Libby and Lift (1993) reveals that the experience will lead to opportunities to acquire knowledge, and knowledge along with the ability will affect the performance of the accountant. An excerpt of the interview of a senior auditor, he gave some hints as follows:

"An auditor may have some kind of feeling whether the transaction is proper or improper, and this has significant effect on the audit procedures to be done, and this can only be proved when he does vouching (tracing of the report into evidence)."

In line with this idea, Indri who is also supervisor who revealed that the longer an auditor is the field, the more he faces clients and the more he becomes sensitive to read the client's character. Indri's understand of the technical aspects such as understanding the scope of the assignment and legal agreements as a form of awareness of the legal liabilities implies a masculine response. Similarly, experience and insight into the development of auditors is also a response form for personal enrichment of a professional.

Human beings constantly face the need to make a decision that may have consequences for themselves and others. Often, ethical dilemmas arising from choices bring about the goodness on the one hand; it does not necessarily bring the goodness to the other party. Boynton (2002: 97) recommends two important questions when facing such situations: "What the goodness am I looking for?" And "What is my liability (responsibility), in such conditions?". Sandi's attitude strongly expresses that an auditor must not have a dilemma in doing the job (attest services).

"Dilemma? No, No such a thing as dilemma. Auditor is independent. What dilemma? Sensitively emotional? If there is a dilemma, that may mean unprofessional. The so-called professionalism was within the corridor, having the legal umbrella, that's it! We talk about the audit, why should we be upset with the two sides? Basically it comes from the flow of audit procedures, if we do not find in accordance with what we expect, it certainly means that we find an error or irregularity there. And if it cannot internally be proved, we will say in the opinion, we exclude, that's it".

Sandi's attitude implies a firm attitude that is more objective, independent, straightforward and free. Not all jobs can be called as a profession. In Roslender (1992), Greenwood gives five characteristics that define a profession. One of them is called a community sanction. The existence of professional accountants in the community is practically also faced with sanctions if they do not perform according to the rules. Legal liability is not only demanded when there is another person or client who will be harmed, but how the accounting profession is constantly aware of the legal responsibility in every implementation of their professional work.

Indri's attitude in dealing with technical aspects such as the scope of audit assignments and a legal agreement suggests that she understand professional meaning in the way she understands legal liability. Sandi who considers that a professional should not have a clear ethical dilemma is an evidence of professionalism. Realizing of the existing community sanction in this case as given by IAI (Ikatan Akuntan Indonesia/Association of Indonesia Accountant) is also a form of self-awareness as a professional accountant. Ultimately, the understanding of the legal liabilities may indicate one thing that is as evidence of their professionalism. As having previously stated, then the attitude of professionalism consist of the meaning of being aggressive, independent, more objective, more competitive, more active, usually always featured as a leader, more self-confident, being able distinguish between emotion and intellect, and more ambitious. All these values are held to be a reflection of masculine characteristics. This masculine meaning of professionalism is the "field" code which was obtained from the Public Accounting Firm study site. The response to this social reality is objectives that are masculine response, mechanical, and down-toearth. So, it can be said that the meaning of "professionalism" is as masculine values.

\section{Legal Liabilities as a Form of Self-Protection by "rolling the hot ball down from the Auditor to Auditee"}

In attestation services the kinds of services that are generally carried out are the general audit, special audit and due diligence. All this has a different risk. "When linked with his own evidence, the evidence is fictitious, what shall be done?" Are all these things will be checked into the field? For example there exist a purchase of raw materials but in fact, the investation is fictitious. This is where the auditors' break-out. Sandi responds to this "Therefore, we always have to look at the scope of the evidence, we speak of evidence, (and more emphatically) we are not talking about 
valid or invalid. We refer to the evidence. "If directed to the law, this suggests that there is no real gap for the auditor to be cornered or feel trapped because if there is evidence the deal is completed (whether in certain circumstances the evidence given by the management might be fictitious and could not be detected by the auditor).

Aside from that, a general auditor must request a Letter of Management Representation. This is a statement from the company management that essentially there are no things being covered up when the audit is conducted, no hidden things stating done for fraud. From what is disclosed above, so by itself in legal language by law, "hot ball has rolled down to the auditee". For that reason the audited company itself is the one that will have all the risk if the company does not present the right thing.

"Not that the accountant is not aware of the adherence to legal liabilities in the profession, precisely because the accountant is aware of it then some things like the problems of evidence, and then ask the management representation letter; it should be given early when the audit commences."

The understanding of the meaning of self-protection for legal liability is also implied from the passage of a chat with the chief of the Public Accountant Firm Mr. Daniel as follows:

"What has been governed by the IAI's just a rule of conduct. Code of ethics, what is allowed and what is not. But the problem of the imposition of sanctions for violations of the profession is not yet clear. That is why an accountant also needs to know the rules and laws other than their professional rules. For example the Consumer Protection Act for consumers who may be harmed by the violations committed by the accountants, then also the problem of civil law..., it is important for an accountant to understand this so that in case an accountant is charged with "stealing a chicken", he must replace with "chicken" too, not with "goat" because he does not understand the problem“.

Findings of understanding "self-protection" is also hinted that means there is a greater force outside the body so that the accountant by the accountants as it needs to make a shield for "secure" their existence. Clients, public as well as litigation is the party that needs to be there. Sheet audit opinion from the auditors that emphasizes auditor limitation of liability management as well as the letter of representation issued by a client who insists that there is no hidden fact that a sheet of ratification of the auditors' legal liability limits. However the audit also involves a consideration of (audit judgments) and this should be understood well by the auditors. Meaning of "self-protection" can also be interpreted as a self-defense or an attempt to fortify them. In this respect, understand and realize the legal liability is a form of effort is an accountant in the firm exposed to the threat of litigation to prevent the occurrence or things that can harm the accounting profession itself. Attitude that tends to survive (self-defense) or self-protection is a feminine character. So, from what is disclosed above, the meaning of self-protection is the feminine values.

\section{Legal Liabilities as a Manifestation of Compliance:-}

Undergo an experience of a general audit practices and audit feasibility for a long history, Indri mature enough to make a commitment in maintaining the profession so that these words are proved through practice. In essence, according to the Indri, "a legal duty to client's auditor is limited responsibilities to the standard." This implies that legal responsibility is understood as a form of adherence to professional standards. Understanding of women about a crime is concrete so that a bad event is an event that dangerous, something that could hurt someone. When talking about the problem of violations conducted by public accountants, Indri more directed to internal self-introspection in which she re-emphasizes that the accountants to stick to the standard. Her attitude is in line with the nature in which women can only be achieved if their expectations are low; they tend to relate it to their own shortcomings in terms of ability or intelligence (Bill, 2003: 13).

Researcher have seen Karto the partner who has been so long wrestle not ashamed of the profession only if the auditor should re-open the "book work". On the desk is open Karto's SPAP book (Standar Profesional Akuntan Publik/ Professional Standard Public Accountant) while he completed his work. Occasionally he was seen reading the SPAP. Agreed with Karto, Indri also been revealed that in the SPAP was included a stage, procedures and considerations that must be done in the audit assignment "... even we sometimes forget that there also should be open again" he said with a laugh. He thinks that it is enough to make us walk on the "railroad".

Broader understanding of a legal awareness is reflected in the attitude of compliance with the law, in this case the accounting professions own rules. Soerjono Soekanto in Salman (2004: 56) expresses the attitude of law is a 
tendency to accept the law because of the respect for law as something useful or beneficial if the law is obeyed. The attitude of this will establish patterns of legal behavior, where from here would be seen whether a rule applies or not in society so that public awareness of how far one can know from this. This attitude implies the feminine in it.

Indri attitude that emphasizes the limited auditor liability to the standards of responsibility implies that legal responsibility is understood as a form of adherence to professional standards. Observations on the figure Karto in daily practice that always refers to the SPAP at his desk also illustrate its compliance with the standards. So, from what has been disclosed above, it can be drawn that line is still the legal responsibility here is understood as a manifestation of compliance.

Meaning of legal liability as a form of compliance or obedience or adherence to contain more passive nature of remembering its position that only implement what has been outlined, more receptive, obedient, and the nature of support. This is a feminine response to reality. Adherence to professional standards is proof of their awareness of legal liabilities. However the legal responsibility issues are not expressly regulated in the professional standards of public accountants, but the interpretation of this is what is emphasized here. It can be concluded that the meaning of compliance is a feminine value.

\section{Legal Liabilities as Part of Moral Responsibility by Realizing "The Problem is the Problem of Moral Breach":-}

Violations committed by the accountant in the practice of his profession cannot be tackled solely by the system of internal control systems or other related professions such as law outside the profession. The mentality of the perpetrators of this must be addressed. Karto revealed that:

"Problem of the violation is moral issues. Right? If someone has good moral, they will remain good. But if morale is not good, rigorous oversight of any kind, whatever that good laws, it will happened like that (meaning violation cases accounting profession practice). Each day supervision does not guarantee there is no violation of regulation".

They are the accountants who violate the rules sometimes do not understand instead of his profession, but gray area that is exploited by them. Intellectual dimension was no guarantee whether the person also has a good level of morality. The statement from Mr. Daniel also supports this:

"The truth is precisely the cases that occurred as Enron was doing by great people. He (the accountant's agents) may control the accounting standards, the knowledge there is no doubt but he will look for the holes. That's a lot of legal gray area, and this gray area that is not much touched by the public. Now between public accountants and public expectation there are gaps, like Arthur Andersen that they are all great people, the largest accounting firms. Like a chicken thief, it appears that the person is not clever. It is different from the corruption case, the perpetrators are scholars and even professors, so very few of them are caught (while laughing)."

Morality can be defined as a guide owned by individuals or groups about something is right or wrong, good or evil. "The problem is the violation as a moral issue." Moral values faced in social reality, especially business and professional environment in part through the reduction of values and attitudes are then more likely idealist in a pragmatic and tolerant attitude towards the prevailing value system (dominant).

However prioritize moral values remains to be done especially in the middle of a materialistic society, as quoted from Stainer (1997: 218) "This is part of a civilization of society that people, inside and outside business, act morally, not less not more ". Awareness of the moral responsibility of each person against another person will place a legal responsibility as well in it. Organizations and individuals should have an obligation beyond that required by law or economic efficiency. Accountants need not only to maintain their technical skills and professional, but also to understand the ethical issues that potential. Gender research aims to create a society free from the characteristics of misfortunes in various forms (Handayani and Sugiarti, 2006). Various misfortunes that struck the accounting profession because of the scandal that they do imply that morality is questionable. From what has been disclosed above, in their view, the legal issue is a moral issue. It is understood by realizing the problem is a violation as the moral issues that must be addressed so that morality violations do not occur. Or in other words, the moral responsibility of a public accountant who shall be repaired so that he/she realizes its legal liabilities, so that violations of professional practice do not happen again. So we can conclude that the legal responsibility understood 
as part of moral responsibility. The value that involves taste, intuition, which in turn builds the ethical dimensions of moral character, is feminine values.

\section{Conclusion:-}

When discussing about legal liabilities, it is important firstly to understand the human consciousness of the law itself. Enlightenment can establish into the souls through awareness (consciousness). This research is to explore the reality of practice in leading to the synthesis of the understanding that the first legal liabitity as evidence of professionalism, secondly, the legal liability as a form of self-protection; third, the legal liabilities as a manifestation of compliance; and the last four, the legal liability as part of moral responsibility. The finding of this understanding is a reflection of awareness of legal liabilities of public accountants in the research site. Meaning of "professionalism" contains the values of the masculine, while the meaning of "self-protection", "compliance" and "morality" contain the feminine values. In practice the value of masculine and feminine are integrated with each other.

"The unexamined life is not worth living" said Socrates. There's something wrong with human life if allowed to run without reflection. The process of reflection of what he had lived, was chosen or practiced making man can see both sides of black and white. In the previous section has revealed that the nature of the submissive, obedient, or tend to follow the existing rules are a reflection of the feminine side. Similarly, moral values are formed by people who often negation by the needs of the values established by reason alone. A professional accountant is not only shaped by rules, norms or normative values but also the values that can enrich the professional personal that comes from the Creator. Moral values need to come along in a professional accountant.

\section{References:-}

1. Arens and Loebbecke. 1997. Auditing: an Integrated Approach. Seventh Edition. Prentice-Hall International.

2. Bill and Pam Farrel. 2003. Laki-Laki Seperti Wafer, Perempuan Seperti Bakmi. Penerbit Andi, Yogyakarta.

3. Boynton, W.C., R.N. Johnson, and W.G. Kell. 2002. Modern Auditing. Edisi Ketujuh. Penerbit Erlangga, Jakarta

4. Burrel, G and G. Morgan. 1979. Sociological Paradigms and Organisational Analysis. Ashgate Publishing Company, USA.

5. Fakih, Mansour. 2006. Analisa Gender dan Transformasi Sosial. Penerbit Pustaka Pelajar, Yogyakarta.

6. Ganado, Max. 2007. Report on The Professional Liability of Accountants and Auditors. http//www.the malta institute of accountants.htm

7. Handayani, Trisakti and Sugiarti. 2006. Konsep dan Teknik Penelitian Gender. Penerbit Universitas Muhamadiyah, Malang

8. Ikatan Akuntan Indonesia. 2001. Standar Profesional Akuntan Publik. IAI-KAP, Jakarta.

9. Irianto, Gugus. 2003. Skandal Korporasi dan Akuntan. Lintasan Ekonomi, 20 (2): 104-114.

10. Kholis, Azilul. I. N. Rata, S. Sulistyowati, and E. P. Lestari. 2001. Kewajiban Hukum (Legal Liability) Auditor. Jurnal Bisnis dan Akuntansi, 3 (3): 507-519.

11. Libby, R and J. Luff. 1993. Determinants of Judgment Performance in Accounting Settings: Ability, Knowledge, Motivation and Environment. Accounting, Organizations and Society. 18 (5): 425-450.

12. Ludigdo, Unti. 2005. Analisis Strukturasi atas Praktik Etika di Kantor Akuntan Publik. Disertasi. Fakultas Ekonomi, Universitas Brawijaya, Malang.

13. Moleong, L.J. 2005. Metodologi Penelitian Kulitatif. Edisi Revisi. Penerbit Remaja Rosdakarya, Bandung.

14. Mufidah. 2003. Paradigma Gender. Penerbit Bayumedia, Malang.

15. Muhadjir, Noeng. 2000. Metodologi Penelitian Kualitatif. Edisi Keempat. Penerbit Rake Sarasin, Yogyakarta.

16. Piliang, Y. Amir. 2006. Dunia yang Dilipat: Tamasya Melampaui Batas-Batas Kebudayaan. Penerbit Jalasutra, Yogyakarta.

17. Roslender, Robin. 1992. Sociological Perspectives on Modern Accountancy. Routledge, London and New York.

18. Saleh, R., S. A. Syahdan., and U. Pratiwi. 2005. Refleksi Tanggungjawab Auditor dan Keterikatan Peran Manajemen dalam Mendeteksi Kecurangan Pelaporan Keuangan. Media Akuntansi, 44: 53-58.

19. Salman, Otje and A. F. Susanto. 2004. Teori Hukum: Mengingat, Mengumpulkan dan Membuka Kembali. Penerbit PT. Refika Aditama, Bandung.

20. Stainer, Alan. L. Stainer and A. Segal. 1997. The Ethics of Tax Planning. A European Review. 6(4): $213-219$.

21. Sumaryono, E. 2002. Etika \& Hukum. Penerbit Kanisius, Yogyakarta. 
22. Susanto, Ari. 2003. Pengaruh Motivasi Kerja, Proses Belajar dan Perkembangan Moral terhadap Persepsi Auditor Independen Mengenai Pelaksanaan Kewajiban Hukum Profesi Auditor Independen (KAP). Skripsi. Fakultas Ekonomi, Universitas Brawijaya, Malang.

23. Tong, Rosemarie Putnam. 2006. Feminist Thought. Penerbit Jalasutra, Yogyakarta.

24. Triyuwono, Iwan. 2006. Plural Is Beautiful: Menimba Kearifan dari Semangat Multiparadigma. Makalah Pelatihan Metodologi Penelitian, Fakultas Ekonomi, Universitas Brawijaya, Malang.

25. Yunitasari, Prawika. 2002. Persepsi Akuntan Publik terhadap Penerapan Private Litigation sebagai Sanksi Pelanggaran Kode Etik Profesi (Studi Kasus pd KAP-KAP di Malang). Skripsi. Fakultas Ekonomi, Universitas Brawijaya, Malang.

\section{Appendix:-}

Table 2:- Findings about Legal Liabilities in the Framework of Masculine and Feminine Values

\begin{tabular}{|c|l|c|c|}
\hline No. & \multicolumn{1}{|c|}{ Understanding } & Indicator & Palues \\
\hline 1 & $\begin{array}{l}\text { Legal Liabilities as Evidence of } \\
\text { Professionalism }\end{array}$ & Self-Protection & Feminine \\
\hline 2 & $\begin{array}{l}\text { Legal Liabilities as a form of Self-Protection } \\
3\end{array}$ & $\begin{array}{l}\text { Legal Liabilities as a Manifestation of } \\
\text { Compliance }\end{array}$ & Compliance \\
\hline 4 & $\begin{array}{l}\text { Legal Liabilities as Part of Moral } \\
\text { Responsibility }\end{array}$ & Morality & Feminine \\
\hline
\end{tabular}

